\title{
The Phison River plume: coastal eutrophication in response to changes in land use and water management in the watershed
}

\author{
Gilles Billen $^{1,2, *}$, Josette Garnier ${ }^{2}$ \\ ${ }^{1}$ FNRS, University of Brussels, CP221, Campus de la Plaine, B-1050 Brussels, Belgium \\ ${ }^{2}$ CNRS, University of Paris VI, Tour 26, $5^{\circ}$ et, 4 place Jussieu, F-75005 Paris, France
}

\begin{abstract}
Human impact on the coastal zone is mainly exerted through riverine nutrient delivery, dependent on land use and management of the watershed. The link between human activity and coastal eutrophication is not direct, however, because of the complexity of the processes involved in the retention or elimination of nutrients during their transfer along the aquatic continuum from land to sea. In order to explore this link, we make use of 2 idealized models respectively representing the ecological functioning of whole drainage networks including their stagnants annexes (the Riverstrahler model) and of river impacted coastal systems (the Zoco model). Coupling of these 2 models, which use exactly the same kinetic formulation for all microbiological processes with only slightly different parameter values, allows simulation of the major trends of the seasonal variations of coastal algal blooms in response to changes in land use in the watershed. The models were applied to a hypothetical rivercoastal zone system (the 'Phison River' and its plume in 'Eden Bight'), for a chronological succession of land use and management scenarios, ranging from the pristine forested watershed to the dense urbanization conditions of Western European industrialized countries. The results show that, as early as the beginning of the 19th century, development of intense blooms of non-diatoms, accompanied by a shift from phosphorus limitation to silica/nitrogen limitation, might have occurred in the coastal zone. In the second half of the 20th century, increased use of nitrogen fertilizers, coming after the suppression of wetlands and buffer strips along rivers, might have again pushed the coastal system to phosphorus limitation, while the introduction of phosphorus-containing washing powders (from the mid 1960s) again reversed this trend. Under the chosen conditions of land use and population density, it was found that elimination of nitrogen from wastewater through generalized tertiary treatment would not produce very significant changes in the eutrophication status of the coastal zone. On the other hand, phosphorus removal from point sources, preferably combined with wetlands restoration, would lead to a drastic reduction of algal blooms with a new shift to phosphorus limitation.
\end{abstract}

KEY WORDS: Eutrophication - Riverine delivery - Silica - Nitrogen · Phosphorus - Land use

\section{INTRODUCTION}

Coastal eutrophication caused by riverine inputs of nutrients is among the most widespread and globally significant anthropogenic impacts on the coastal ocean. In spite of the diversity of its local manifestations, some common trends exist allowing one to distinguish the process of river induced eutrophication from that of up-

\footnotetext{
•E-mail: gbillen@biogeodis.jussieu.fr
}

welling induced enrichment. Marine coastal eutrophication is characterized by a strong increase of primary production most often restricted to a narrow area along the coast, or within the plumes of large rivers. It is characterized by a shift of the communities from a dominance of diatoms and their crustacean predators in unaffected coastal areas, to a dominance of non-diatoms ('flagellates', including dinoflagellates, chrysophytes, chlorophytes, coccolithophoridae and bluegreen algae), with increasing importance of the microbial foodweb, in perturbed systems. How these changes in eco- 
system structure might be explained by the altered balance of the terrigenous inputs of silica, nitrogen and phosphorus has been discussed by Officer \& Ryther (1980) and Conley et al. (1993).

A striking and well-documented example of a eutrophicated area is provided by the continental coastal zone of the Southern Bight of the North Sea, receiving the nutrient load carried by the large rivers which, from the Seine to the Elbe Rivers, are draining one of the most populated and industrialized areas in the world. Late spring blooms of Phaeocystis, following a small diatom bloom, reach a biomass as high as $50 \mu \mathrm{g}$ chl $\mathrm{al}^{-1}$ in the Belgian and Dutch coastal zone, where they give rise to massive foam accumulation (Lancelot et al. 1987, 1997. Cadée \& Hegemann 1991). The plume area of the River Po, in the Northern Adriatic Sea, is another example of a eutrophicated area, with recurrent accumulation of gelatinous material causing oxygen depletion in bottom water (Degobbis 1989, Marchetti 1991).

Evidence for tracing back the past trends of coastal eutrophication is obviously scarce. For the 2 examples cited above, however, some indications exist. A long series of quantitative data collected since 1962 at Helgoland (Germany) (Radach et al. 1990) shows a continuous increase of winter nitrate (but not silica) concentrations, and a corresponding trend of increasing flagellate (but not diatom) biomasses. Cadée \& Hegemann (1991) have recorded the seasonal variations of phytoplankton successions in the Marsdiep area (Texel, The Netherlands) since 1971. Their data show a general trend of increasing duration of Phaeocystis blooms during late spring and summer. The same trend has been observed in the Belgian coastal zone (Lancelot \& Billen 1992). On the other hand, Cadée \& Hegemann (1991) also uncovered data on Phaeocystis occurrences dating back from the end of the 19th century and showing a development of Phaeocystis quite similar to the present one. This is also consistent with the work of Grossel (1985) who carefully looked at oral traditions and colloquial terms used by fishermen in the Pas de Calais district of France. These observations clearly show that coastal blooms of Phaeocystis, which clogged the nets and made the water smell unpleasant, were common about 50 yr before the increase observed since the iğfus. Similarly, in the Adriatic Sea, although the eutrophicationrelated 'Mare Sporco' events have been obviously increasing in frequency and intensity since the 1970 s (Justic et al. 1987), a large number of records of similar events have been found in the literature between 1872 and 1931 (Fonda Umani et al. 1989).

This suggests that a century ago, there might have been a wave of eutrophication preceding the one presently observed. Some authors concluded that other factors than nutrient enrichment, e.g. long-term climatic variations, are primarily responsible for the observed trends (Owens et al. 1989).

One aim of the work presented here is to suggest another interpretation, based on a detailed examination of how coastal eutrophication may result from land use and human activity in the terrestrial watershed. This relationship is far from being direct because of the complexity of the processes determining the release of nutrients from terrestrial systems to surface water, and their retention/elimination during their transfer along the aquatic continuum from land to sea. Recent budget studies at both regional and global scales show indeed that only a limited fraction of nutrients discharged into surface water by human activity ultimately reaches the open ocean, most of them being trapped or eliminated in wetlands, river channels, reservoirs, estuaries or the coastal zone itself (Billen et al. 1991, Howarth et al. 1996). The approach developed to discuss the complex link between land use and coastal eutrophication consists of coupling 2 idealized biogeochemical models: the Riverstrahler model of whole drainage networks and the Zoco model, a derived coastal zone model based on the same representation of the biogeochemical processes. The Riverstrahler model was developed to represent the ecological functioning of large river systems including their stagnant annexes (Billen et al. 1994. Garnier et al 1995). It has been applied to and validated in a number of European river systems (Billen et al. 1995). A quite similar model has been established for coastal systems, simulating the major trends of the seasonal variations of algal blooms in response to nutrient enrichment. Coupling these 2 models offers a way to explore the response of the whole aquatic continuum, from headwaters to the coastal zone, to various scenarios of land use and water management in the catchment.

Here, we apply these models to the hypothetical case of the Phison River and its plume. Phison, according to the Bible, is the first stream of Eden; 'It is draining the land of Hevilath, where gold is found' (Genesis I, 2). We will consider a chronological succession of watershed use and management scenarios, ranging from the pristine forest to the dense urbanization conditions of Western European industrialized countries.

\section{MODEL DESCRIPTION}

The coupled models used in this study rest on a common description of the kinetics of the basic processes determining the ecological functioning of aquatic systems: the RIVE model. The structure of RIVE, which summarizes the results of about 20 yr of microbial ecological research, is described in Fig. 1. It includes a 


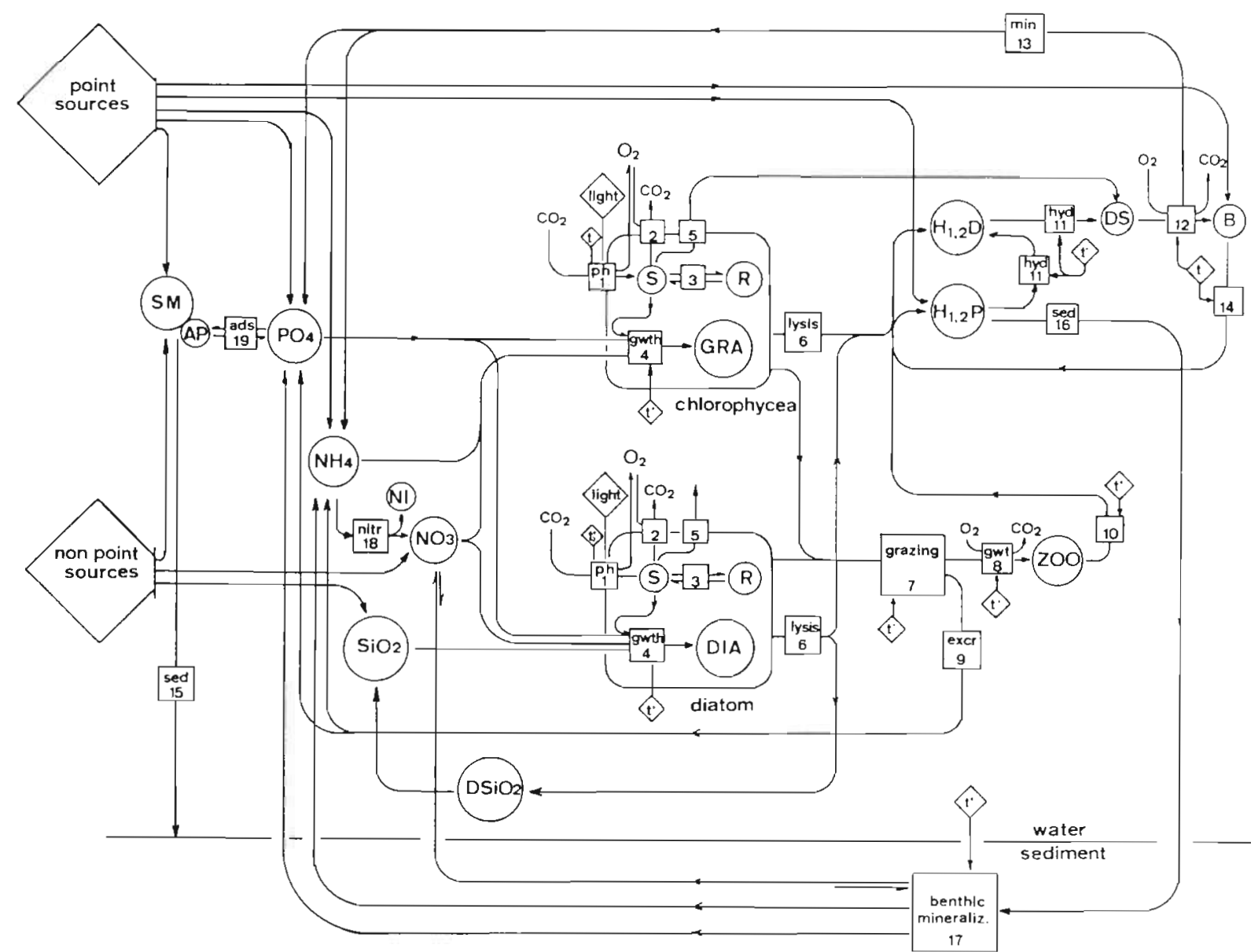

State varjables include

DIA: dialoms

GRA: green algac (chlorophyceae)

both with $S:$ intracellular low molecular weight motabolites

R: potymeric reserve compoumels

DIA/GRA: functional and structural melabolites

ZOO: zooplankion

$\mathrm{H}_{1} \mathrm{D}$ : rapidly hydrolysable dissolved organic matter

$\mathrm{H}_{2} \mathrm{D}$ : slowly hydrolysable dissolved organic matter

$H_{j} P$ : rapidly hydrolysable particulate organic maller

$H_{2}$ P: slowly hydrolysable particulate organic matler

DS : directly utilisable monomeric substrates

$\mathrm{B}$ : bacleria

$\mathrm{NH}_{4}$ : ammonium

$\mathrm{NO}_{3}$ : nitrate

NI : nitrifing bacteria

$\mathrm{SiO}_{2}$. dissolved silica

$\mathrm{DSiO}_{2}$. detrital particulate silica

$\mathrm{PO}_{4}$ : dissolved ortho-phosphate

AP : adsorbed ortho-phosphate

$\mathrm{SM}$ :suspended inorganic malerial
Processes laken into accoun are:

1 carbon fixation through photosynthesis

2 algal respiration

3 rescrve symthesis and catabolism

4: growth (i.e. synthesis of functional melabolites)

5 : excretion

$6 \cdot$ Jysis

7 rooplankion grazing

8. rooplankton growh and respration

9 : zooplankion excretion

10: zooplankton mortality

11 : hydrolysis of polymeric organic matter

12: bacterial growih and respiration

13: bacterial excretion of ammonium and phosphiale

14: bacterial mortality

15: sedimentation of particulate inorganic matesial

16: sedimentation of particulate organic matter

17: benthic nutrient mineralization recycling

18: wales column nitrification

19: $\mathrm{PO}_{4}$ adsorption onto suspended matter

Fig. 1. Schematic representation of the variables and processes considered in the RIVE model of ecological functioning of aquatic systems (see Billen et al. 1994 and Garnier et al. 1995 for details)

detailed description of phytoplankton activities (distinguishing between diatoms and non-diatoms), zooplankton grazing, planktonic organic matter degradation, nitrification and benthic remineralization. Nitrogen fixation is not taken into account. A complete description of RIVE is provided elsewhere (Billen et al. 1994, Garnier et al. 1995, Sanchez et al. in press). The value of the kinetic parameters for the river system are those provided in Garnier et al. (1995). For the coastal zone model, some differences, listed in Table 1, were introduced for characterizing seawater phyto- and zooplankton communities from their freshwater counterparts. Except for these minor differences in the value of the parameters, exactly the same representation is 
Table 1. Compared physiological parameters used in the RIVE model for freshwater versus marine phytoplankton and zooplankton. $\mathrm{dti}$ : parameter expressing the range of temperatures below the optimum temperature at which significant activity is found

\begin{tabular}{|c|c|c|c|c|c|}
\hline \multirow{2}{*}{ Parameter } & \multirow{2}{*}{ Unit } & \multicolumn{2}{|c|}{ Freshwater } & \multicolumn{2}{|c|}{ Seawater } \\
\hline & & Diatom & Chlorophyll & Diatom & Non-diatom \\
\hline Optimal growth rate & $h^{-1}$ & 0.06 & 0.12 & 0.05 & 0.05 \\
\hline Maximum photosynthetic rate & $h^{-1}$ & 0.25 & 0.5 & 0.15 & 0.15 \\
\hline P/I initial slope & $\mathrm{h}^{-1} /\left(\mu E \mathrm{~m}^{-2} \mathrm{~s}^{-1}\right)$ & 0.0015 & 0.0015 & 0.0015 & 0.0015 \\
\hline$K_{\mathrm{s}} \mathrm{N}$ inorganic & $\mu \mathrm{M}$ & 5 & 5 & 0.5 & 0.5 \\
\hline $\mathrm{K}_{\mathrm{s}} \mathrm{PO}_{4}$ & $\mu \mathrm{M}$ & 0.5 & 1.5 & 0.2 & 0.2 \\
\hline$K_{\mathrm{s}} \mathrm{SiO}_{2}$ & $\mu \mathrm{M}$ & 7 & - & 0.5 & - \\
\hline $\mathrm{Si} / \mathrm{C}$ & molar & 0.42 & - & 0.15 & - \\
\hline Optimal temperature & ${ }^{\circ} \mathrm{C}$ & 13 & 17 & 8 & 12 \\
\hline \multirow[t]{2}{*}{ Temperature range (dti) } & ${ }^{\circ} \mathrm{C}$ & 21 & 37 & 2 & 5 \\
\hline & & \multicolumn{2}{|c|}{ Freshwater } & \multicolumn{2}{|c|}{ Seawater } \\
\hline Optimal growth rate & $h^{-1}$ & \multicolumn{2}{|c|}{0.06} & \multicolumn{2}{|c|}{0.005} \\
\hline Maximum grazing rate & $h^{-1}$ & \multicolumn{2}{|c|}{0.135} & \multicolumn{2}{|c|}{0.02} \\
\hline Half-saturation const of grazing & $\mathrm{mgCl^{-1 }}$ & \multicolumn{2}{|c|}{0.4} & \multicolumn{2}{|c|}{0.01} \\
\hline Threshold phyto-concentration & $\mathrm{mg} \mathrm{Cl}^{-1}$ & \multicolumn{2}{|c|}{0.1} & \multicolumn{2}{|c|}{0.01} \\
\hline Mortality rate & $h^{-1}$ & \multicolumn{2}{|c|}{0.005} & \multicolumn{2}{|c|}{0.0025} \\
\hline Optinal temperature & ${ }^{\circ} \mathrm{C}$ & \multicolumn{2}{|c|}{21} & \multicolumn{2}{|c|}{10} \\
\hline Temperature range (dti) & ${ }^{\circ} \mathrm{C}$ & \multicolumn{2}{|c|}{13} & \multicolumn{2}{|c|}{6} \\
\hline
\end{tabular}

adopted for the processes occurring from headwater streams to the coastal zone. One important feature invoked by several authors to explain the shift in phytoplankton communities observed in eutrophicated systems is a greater competitiveness of diatoms with respect to non-diatoms in the absence of silica depletion (Officer \& Ryther 1980, Conley et al. 1993). Although dominance of diatoms when silica is non-iimiting has indeed often been observed in competition experiments carried out either in the laboratory (Sommer 1994) or in enclosures (Doering et al. 1989, Egge \& Aksnes 1992), we were unable to find evidence in the literature that diatoms are systematically characterized by higher values of growth rate or lower values of $K_{\mathrm{s}}$ (half-saturation constant) for nitrogen and phosphorus uptake, with respect to non-diatoms. Diatoms, on the other hand, seem better adapted to lower temperatures than most non-diatoms (Garnier et al. 1995) (Table 1).

While their description of the internal biogeochemical processes is identical, the specificity of the 2 models lies in the way they represent, for their respective systems, the external constraints related to climate, morpnology, hyciroluyy and inpuis of maitend (Fig. 2).

The river system model (Riverstrahler; Billen et al. 1994, Garnier et al. 1995) is based on the concept of stream order (Strahler 1957): it describes the complex network of tributaries by a regular scheme of confluence of tributaries of increasing stream order with average morphological characteristics. The possible presence of lentic annexes in communication with each stream order tributary is taken into account. A simplified hydrological model of the rainfall-discharge relationship makes it possible to calculate, from the seasonal variations of rainfall and evapotranspiration, the discharge corresponding to surface land sub-surface) runoff and to base flow (hence the flow velocity and depth) for each stream order. Point and non-point inputs of all state variables from the watershed are taken into account.

The coastal zone model considers a body of seawater of stated depth and area, assumed to be vertically and horizontally well mixed, and flushed at a constant rate with 'ocean' water. The composition of this 'ocean' water is calculated by first running the same model, for several annual cycles, for the conditions of a closed water column (with initial N:P:Si stocks typical of North Atlantic conditions), with no sedimentation or benthic activities. The coastal zone receives the riverine inputs of total $N, P$ and Si calculated by the river system model.

\section{CONSTRAINTS CHARACTERIZING THE SCENARIOS}

The Plisurin River will be ussuirised to be a typicul gth order river system, with a catchment of $65000 \mathrm{~km}^{2}$ and the morphological characteristics of Atlantic rivers of Europe (Billen et al. 1995). The climatic constraints considered are the mean temperature, light intensity, rainfall and evapotranspiration of the Seine river system (Billen 1993). They result in a typical pluviooceanic regime, with winter maximum and end summer minimum flow. The Phison River flows into Eden Bay, a $20 \mathrm{~m}$ deep, $1000 \mathrm{~km}^{2}$ coastal zone, flushed by 

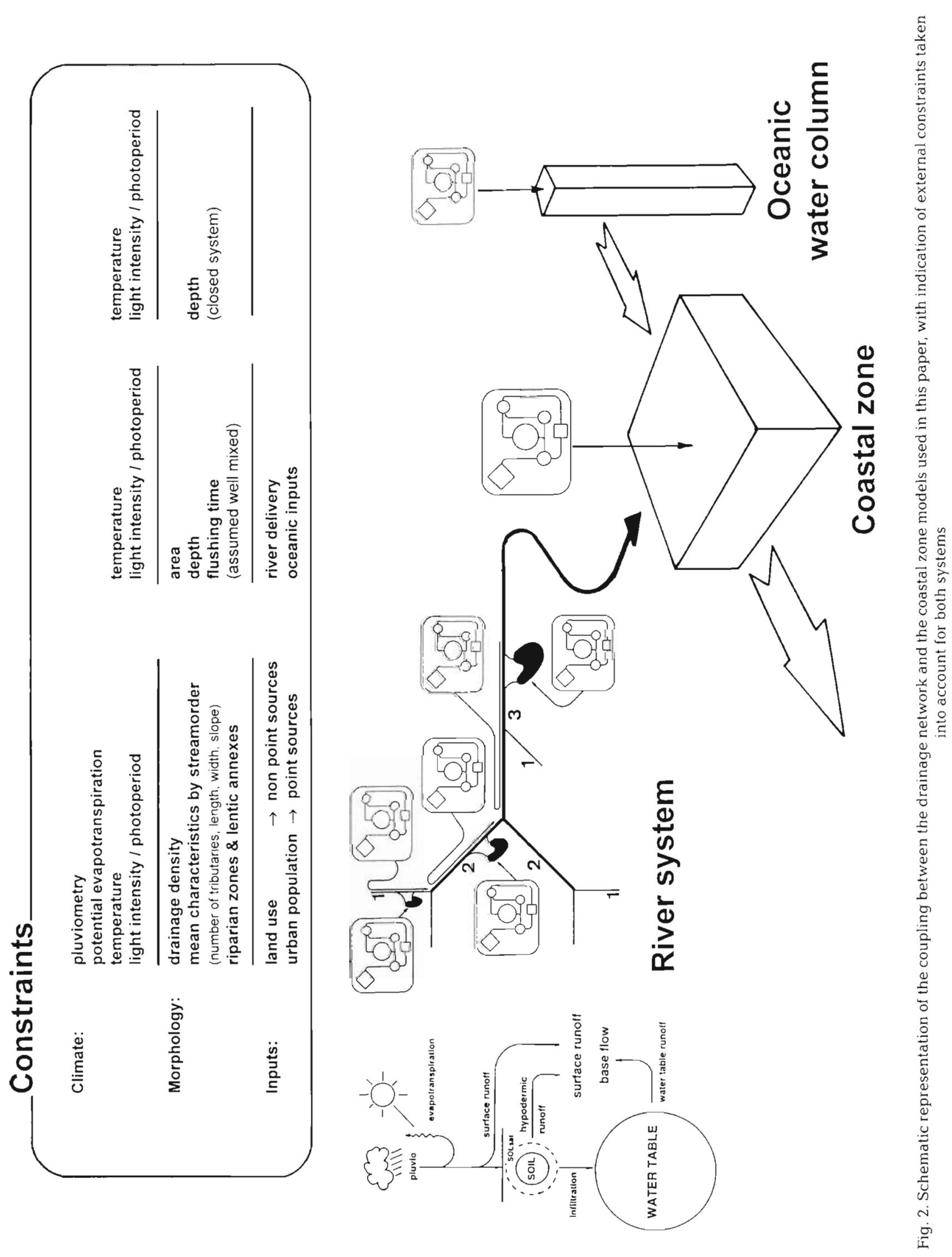
Eden Ocean current with a residence time of $45 \mathrm{~d}$. The resulting salinity in Eden Bay varies between 30 and $33 \mathrm{psu}$. Temperature ranges from 2.5 to $17.5^{\circ} \mathrm{C}$. These characteristics are typical of many river influenced areas of the North Atlantic coast line.

The scenarios considered in this study differ only in the degree of anthropogenic perturbations of the Phison River system. These involve (1) changes in the morphology of the drainage network, (2) changes in diffuse release of nutrients and organic matter resulting from land use in the watershed, and (3) point discharge of wastewater from urban agglomerations.

River system morphology. The morphology of the river system in Europe has been extensively altered since the Middle Ages (10th to 12th centuries). At that time, hydraulic energy from water mills played a major role in many activities. Installation of these mills, along with the construction of dikes and the creation of ponds all along the drainage network, resulted in a succession of fast-and slow-flowing stretches in most river basins. For the basin of the river Zenne, in central Belgium, a detailed census of the number and area of ponds by stream order has been carried out on the basis of ancient topographic maps of central Belgium (Oncklincx 1991). The obtained figures have been used to characterize the morphology of the Phison drainage network in our Middle Ages scenario (Table 2). After the introduction of the steam engine (mid 19th century), many of these ponds were filled. Moreover, from the same period on, drainage of wetlands became widespread which resulted in a progressive acceleration of flow in headwaters. On the other hand, development of transport and trade led to large-scale works of canalization and depth regulation by sluice-locks on the major rivers of Western Europe. Except in cases of major floods, these works are able to maintain the depth of most 7 th order rivers close to $3-4 \mathrm{~m}$, irrespective of discharge.

Non-point nutrient sources. Diffuse sources of nutrients from the watershed result from soil-water interactions. They are taken into account in the River- strahler model by consideration of constant concentrations in surface runoff and base flow respectively.

As far as silica is concerned, these concentrations mostly result from rock weathering, with biological processes playing a minimal role (Meybeck 1986). They therefore vary, according to the lithology of the watershed, between $50 \mu \mathrm{mol} \mathrm{l}^{-1}$ (in the case of detrital alumino-silicate rocks or chalk) and $250 \mu \mathrm{mol} \mathrm{l}^{-1}$ (in the case of sandstone or igneous rocks), irrespective of vegetal cover and land use. Note that these concentrations are 10 to 50 times higher than typical winter offshore seawater values. Values of 150 and $200 \mu \mathrm{mol} \mathrm{I}^{-1}$ for surface and groundwater respectively are considered for the Phison basin, corresponding to a typical sedimentary lithology.

In contrast to silica, nitrogen leaching (mainly as nitrate) is mostly under biotic control. Benoit et al. (1995) and Howarth et al. (1996) summarized the results of direct measurements (using tile drains lysimeters or porous candles) of nitrate concentration in soil water below the root zone for various land cover types and nitrogen inputs (as fertilizer or atmospheric deposition). The much higher leaching of areas not permanently covered by vegetation is quite apparent from these data, as is the effect of increasing fertilizer inputs. For similar land use, sandy soils are subject to a much higher nitrogen leaching than loamy or clayey soils. On the basis of these data, we established the following empirical formula to calculate the mean nitrate concentration in surface runoff from land use in the Phison River watershed

$$
\begin{aligned}
& \mathrm{NO}_{3 \mathrm{~s}}\left(\mu \mathrm{mol} \mathrm{J^{-1 }}\right)=\text { fo } \times 10 \mu \mathrm{mol}{ }^{-1} \\
& +\mathrm{gr} \times\left[20 \mu \mathrm{mol} \mathrm{l} \mathrm{l}^{-1}+2.3 \mu \mathrm{mol} \mathrm{l}^{-1}\left(\mathrm{~kg} \mathrm{~N} \mathrm{ha}^{-1} \mathrm{yr}^{-1}\right)^{-1} \times \text { fertgr }\right] \\
& +\mathrm{cr} \times\left[140+7 \mu \mathrm{mol} \mathrm{l} \mathrm{l}^{-1}\left(\mathrm{~kg} \mathrm{~N} \mathrm{ha}^{-1} \mathrm{yr}^{-1}\right)^{-1} \times \text { fertcr }\right] \\
& +\mathrm{rc} \times\left[140+9.5 \mu \mathrm{mol} \mathrm{I}^{-1}\left(\mathrm{~kg} \mathrm{~N} \mathrm{ha}^{-1} \mathrm{yr}^{-1}\right)^{-1} \times \text { fertrc }\right]
\end{aligned}
$$

where fo, gr, cr and rc represent the fraction of watershed area covered with forest, grassland, cereals or rowcrops (maize etc.) respectively, and fertgr, fertcr and fertrc are the corresponding amounts of fertilizer

\begin{tabular}{|c|c|c|c|c|c|}
\hline \multirow[t]{2}{*}{ Stream order } & \multicolumn{2}{|c|}{ Frequency of pond occurrence } & \multirow[t]{2}{*}{ Fraction of flow diverted } & \multicolumn{2}{|c|}{ Mean pond area (ha) } \\
\hline & Middle Ages & Mid 19th & & Middle Ages & Mid 19th \\
\hline 1 & 0.5 & 0.25 & 1 & 1 & 1 \\
\hline 2 & 0.75 & 0.35 & 1 & 5 & 5 \\
\hline 3 & 1 & 0.5 & 1 & 15 & 15 \\
\hline 4 & 1 & 0.5 & 0.5 & 30 & 15 \\
\hline 5 & 1 & 1 & 0.3 & 60 & 30 \\
\hline 6 & 1 & 1 & 0.2 & 100 & 50 \\
\hline 7 & 0 & 0 & 0 & - & - \\
\hline Total pond area (ha) & & & & 15500 & 7250 \\
\hline
\end{tabular}
applied, in $\mathrm{kg} \mathrm{N} \mathrm{ha} \mathrm{a}^{-1} \mathrm{yr}^{-1}$.

Table 2. Distribution of ponds in the drainage network of the Phison River in the Middle Ages and in the mid 19th century (figures inspired by the detailed census carried out for river Zenne on the basis of ancient topographic maps by Oncklincx 1991) 
Nitrate concentration in groundwater is taken as half the value calculated for surface runoff, in order to account for the observation that nitrate groundwater contamination is often lower than that of surface water (Chestérikoff et al. 1992).

Due to strong adsorption onto clay minerals and iron oxides of the soil, leaching of phosphate from clayey or loamy soils is generally limited and erosion represents the major process of phosphorus addition to surface water from non-point sources. Dillon \& Kirchner (1975) showed a significant difference between the export of total phosphorus from forested watersheds on igneous rocks (mean $4.7 \mathrm{~kg} \mathrm{P} \mathrm{km} \mathrm{km}^{-2}$ $\mathrm{yr}^{-1}$ ) versus sedimentary rocks (mean $11.7 \mathrm{~kg} \mathrm{P} \mathrm{km}^{-2}$ $\mathrm{yr}^{-1}$ ). For grassland dominated watersheds, the corresponding values cited by the same authors are 10.2 and $23.3 \mathrm{~kg} \mathrm{P} \mathrm{km} \mathrm{kr}^{-1}$ respectively. These figures are in good agreement with the ranges of total phosphorus export rates given for forested and grassland watershed by different authors (Omernik 1976, Baldwin et al. 1977, Sonzogni et al. 1980). When data on the speciation of phosphorus in runoff water are available (Vollenweider 1968, Gächter \& Furrer 1972, Sonzogni et al. 1980) they show that, at most, half the phosphorus load is soluble and biologically available. This proportion is still lower (often $<10 \%$ ) in runoff from cropped watershed: indeed, erosion plays a much more important role in phosphorus export from cropland than from forest and grassland, resulting in much higher and much more variable total phosphorus export rates (20 to $500 \mathrm{~kg} \mathrm{P} \mathrm{km}{ }^{-2} \mathrm{yr}^{-1}$, mostly in particulate form; Sonzogni et al. 1980, Beaulac \& Reckhow 1982), without an obvious relationship with the level of fertilization. On this basis, and considering the annual runoff rate calculated for the Phison watershed (240 mm), runoff water concentration values considered in the model are $0.5 \mu \mathrm{mol} \mathrm{P} \mathrm{l}^{-1}$ for forested watershed, $1.5 \mu \mathrm{mol} \mathrm{P}^{-1}$ for grassland and

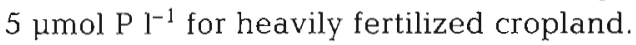

The scenarios we consider for the Phison watershed are consistent with the major trends of land use changes observed in Western Europe (Richards 1990, Williams 1990), namely an intense deforestation in the 11 th and 12 th centuries, followed by a period of stability characterizing the traditional rural economy, with about $50 \%$ forest, $25 \%$ grassland and $25 \%$ cereals cropland (with minimal fertilization, about $5 \mathrm{~kg} \mathrm{~N} \mathrm{ha}^{-1}$ $\mathrm{yr}^{-1}$ ), followed again from the end of the 18 th century by a decrease in forested areas and an increase in cropland. Use of fertilizers only became massive after the middle of the 20 th century.

The nutrient concentrations resulting from rainwatersoil interactions, calculated from land use as described above, represent the upstream limit conditions of the drainage network. Particularly in the case of nitrate, the actual concentration observed in first order tributaries of actual river systems are often lower by a factor of 2 to 5 with respect to the results of these calculations. The reason is that riparian zones with permanent vegetation are sites of quite efficient denitrification, reducing the nitrogen concentration of both subsurface and groundwater flow by about $80 \%$ for a width of $10 \mathrm{~m}$ (Vought et al. 1995). Such forested buffer strips were very common in the traditional rural landscape of Western Europe. By the middle of the 19th century, however, drainage of agricultural land became a general practice and resulted in many regions in the complete suppression of the filter effect of riparian zones.

Terrigenous organic material discharge. Direct discharge of terrigenous organic material constitutes an additional allochthonous input to the river system. In forested watersheds, litter fall plays an important role as a source of organic matter in headwaters. It represents about $200 \mathrm{~g} \mathrm{C} \mathrm{m}^{-2}$ channel area $\mathrm{yr}^{-1}$ (range 25 to 400) (Dawson 1976, Bell 1978, Cummins et al. 1980, Herbst 1980), making about $0.8 \mathrm{~kg} \mathrm{C} \mathrm{km}^{-2}$ watershed $\mathrm{d}^{-1}$. The C:N:P (molar) composition of this material is 1250:16:1 (Meybeck 1982).

In densely populated and urbanized watersheds, point discharge of wastewater is a major source of material for river systems. It results either from domestic activity or from industrial processes. The release of domestic 'liquid' wastes into surface water is a characteristic of urbanization. In most traditional agricultural life systems, human (as well as animal) excrement and domestic wastes are recycled onto cropland. As early as the Middle Ages in Western Europe, however, a primitive system of wastewater collection, often benefiting from the presence of small streams, was organized even in small urban agglomerations for evacuation of domestic wastes to rivers. Modern-type large sewer systems were installed in most large cities during the first half of the 19th century. Disposal of part of the collected wastewater onto cropland was often organized, but direct discharge into rivers dominated. Biological treatment of wastewater in centralized purification plants began in the early 20 th century, but became a general practice only after the 1950s.

Current value of the pollution load corresponding to the mean daily per capita production of domestic wastewater is defined as the 'inhabitant-equivalent'. Presently, it represents about $19 \mathrm{~g} \mathrm{~d}^{-1}$ biodegradable organic carbon, $10 \mathrm{~g} \mathrm{~d}^{-1}$ nitrogen and $3.5 \mathrm{~g} \mathrm{~d}^{-1}$ phosphorus (P. Servais, J. Garnier, N. Demarteau, N. Brion \& G. Billen unpubl.). Reliable analyses of domestic wastewater in Europe have also been available since the second half of the 19th century because of the interest in their agricultural utilization (Billen et al. 1995). These data show a remarkable constancy of per capita nitro- 
gen load since the end of the last century. As far as phosphorus is concerned, it is well known that its presence in domestic wastewater, above a 'physiological' background of about $1.2 \mathrm{~g} \mathrm{P}$ inhab. ${ }^{-1} \mathrm{~d}^{-1}$ (Verbanck et al. 1989), is mostly dependent on the use of polyphosphate-containing washing powders. These were introduced in the 1960s and are now being substituted in many European countries by products using other chelating agents. Accordingly, per capita phosphorus load has experienced a 5 -fold increase in the period 1970 to 1985 , and is now decreasing again towards its physiological level (Billen et al. 1995).

Much more difficult to evaluate, particularly for historical times, is the pollution load caused by industrial activities. Although it presently represents no more than $30 \%$ of total point load of nutrients in most Western European watersheds, a retrospective analysis of the pollution caused by industrial activity at the end of the 19th century showed that it might represent at that time as much as $3 \times$ the domestic load (Billen et al. 1995). Indeed, many late 19th century industrial sectors (like breweries, tanneries, millineries, cotton and wool bleaching and dyeing factories, glue and gelatine factories, candles and soap factories, sugar refineries, paper plants, etc.) already used on an industrial scale fabrication processes identical to those in use several centuries before on a cottage industry scale, which often involved long maceration or the use of e.g. plant decoctions, animal excrement, or blood (Oncklincx 1991, Billen et al. 1995).

Fig. 3 summarizes the historical variations of the major factors characterizing the succession of land use and management scenarios for the Phison watershed. Some actual data for specific watersheds are shown for comparizon. Fourteen successive scenarios, from the pristine state to several variants of intensive agricultural and densely urbanized conditions, are considered for runniny lihe nuviel; the y are listed and described in Table 3.

\section{RESULTS}

\section{Pristine scenario}

When run in the absence of river delivery, the coastal zone model predicts a succession of diatom and non-
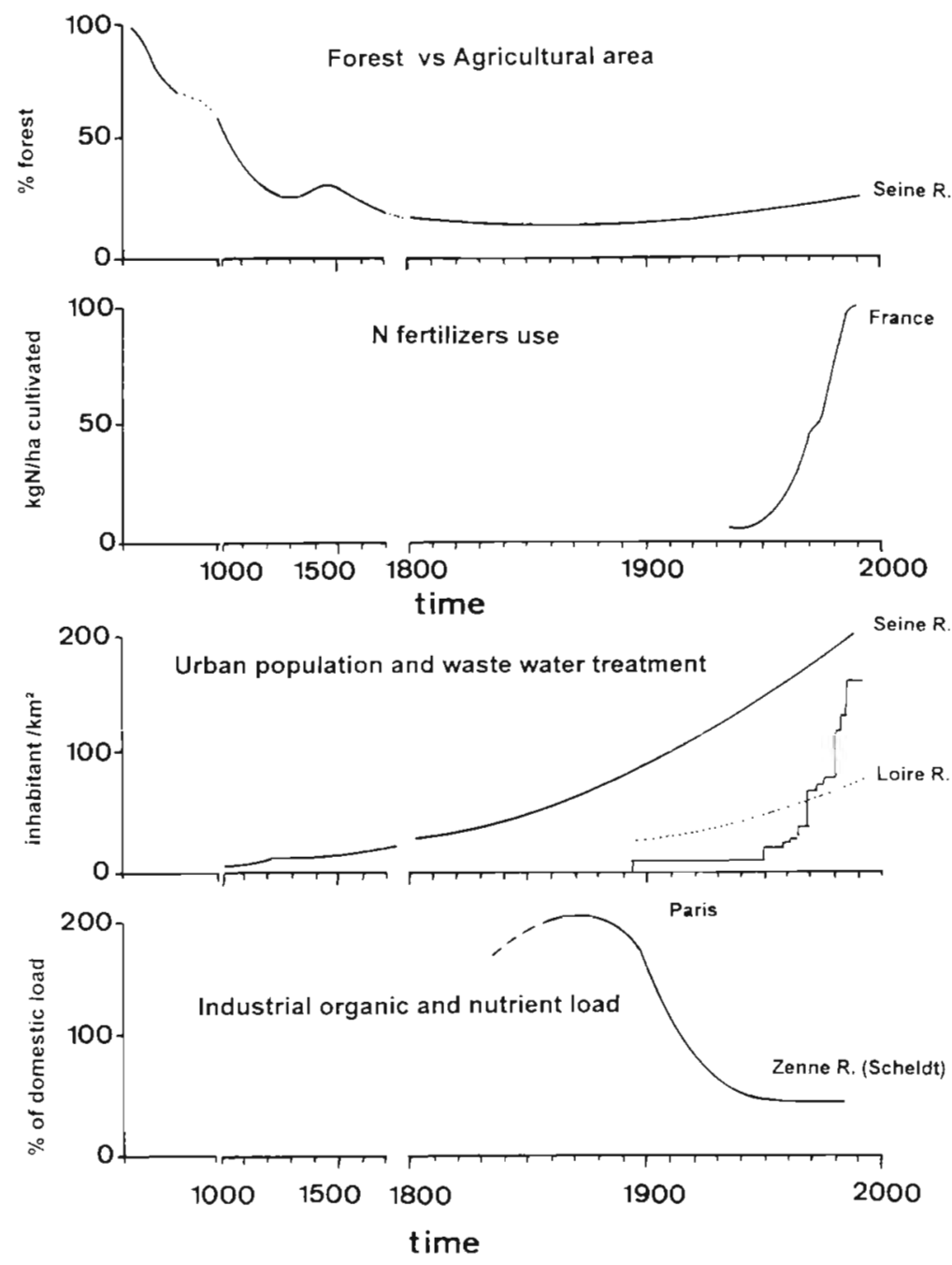

Fig. 3. Major trends of historical variations of land use, urban population, wastewater treatment and industrial loading in Western Europe during the last millennium

diatom blooms of similar importance. Termination of the diatom bloom is caused by the exhaustion of silica, while the non-diatom bloom, simultaneously limited by $\mathrm{N}$ and $\mathrm{P}$, clearly corresponds to a phase of regenerated production (Fig. 4a). The effect of the pristine river delivery, with very high Si:N and Si:P ratios (Table 3, Fig. 4), completely modifies this pattern, and induces a complete dominance of diatoms, which do not exhaust silica. Phosphorus is the limiting nutrient throughout the summer.

\section{Deforestation scenario}

Deforestation of $25 \%$ of the Phison watershed area results in a dramatic increase of nitrate transfer from soil to surface water. In spite of important retention/ 


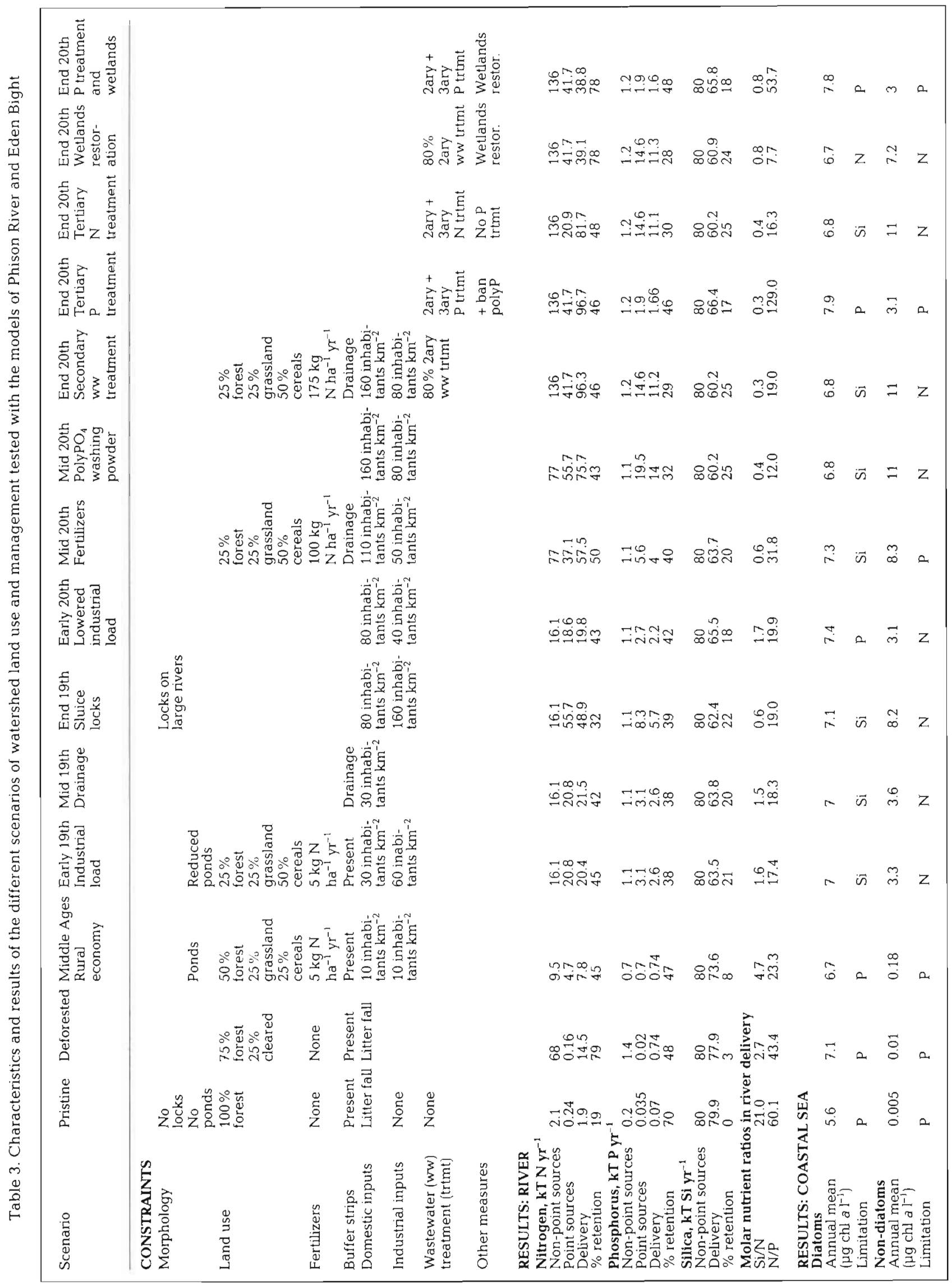


12

Aquat Microb Ecol 13: 3-17, 1997
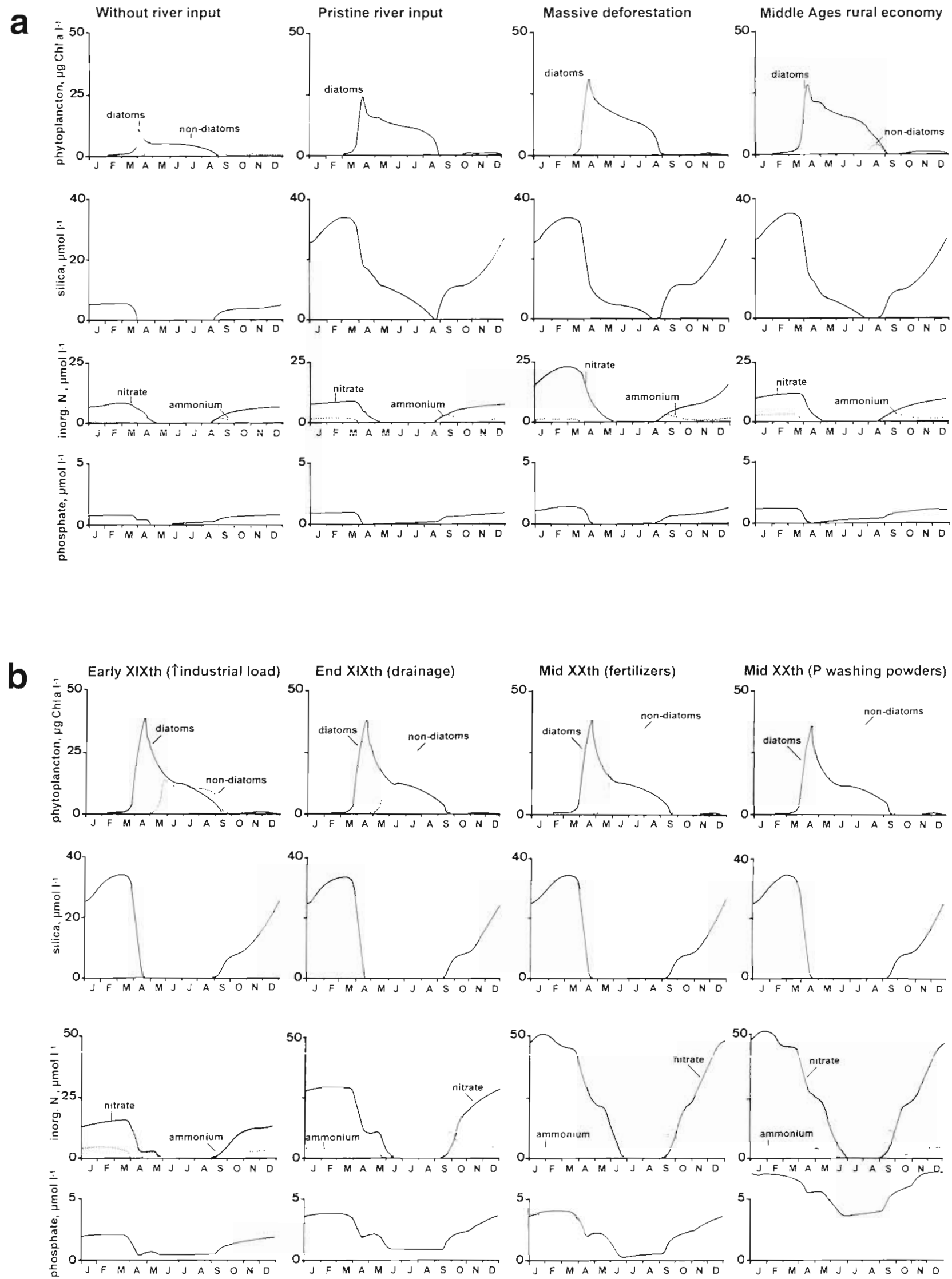

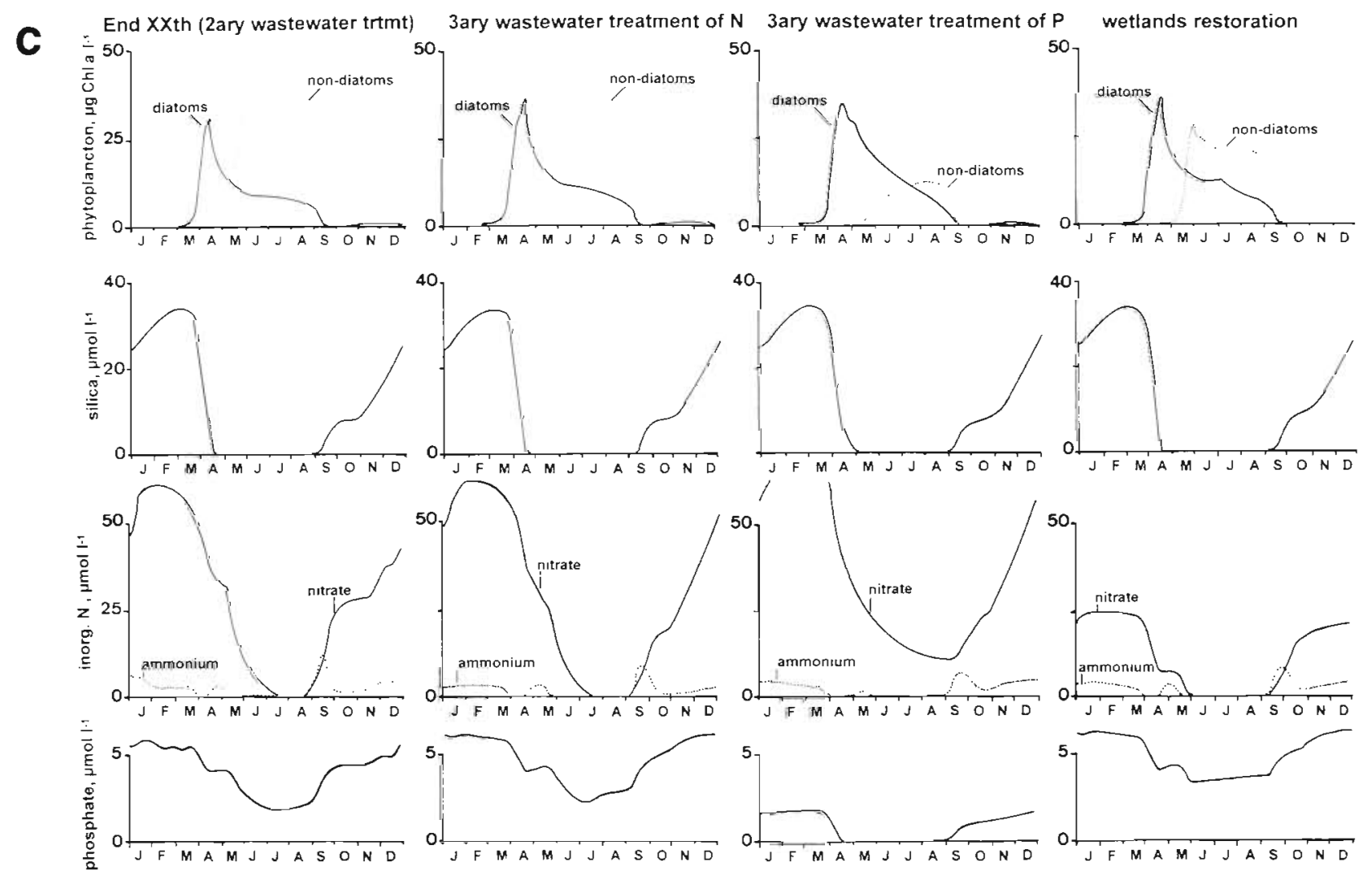

Fig. 4 (facing page and above). Seasonal variations of diatom and flagellate biomass and nutrient concentrations in Eden Bay, simulated by the model for the riverine delivery corresponding to different scenarios regarding land use and water management of River Phison watershed: (a) from pristine conditions to the Middle Ages rural economy; (b) from the early 19 th century to the mid 20 th century; (c) present day conditions and future scenarios of tertiary wastewater treatment and wetland restoration

elimination processes within the drainage network and the riparian zones, nitrogen delivery to the coastal zone is higher by a factor of 8 with respect to the pristine situation. Phosphorus transfer to surface water is less affected, but as retention processes are less efficient, rivers deliver 10 times more phosphorus than in the pristine scenario. Silica delivery is nearly unchanged. Coastal algal growth is stimulated by the higher phosphorus delivery, but not to the extent of causing a change in the diatom/non-diatom dominance pattern, nor in the status of phosphorus limitation.

\section{Middle Ages cottage economy}

Under the conditions of the traditional cottage economy of the Middle Ages, nitrogen and phosphorus deliveries are about 4 -fold higher than in the pristine conditions. Enhanced algal growth in the drainage network and its stagnant annexes causes a significant retention of silica $(8 \%)$. Despite this, phosphorus remains the limiting nutrient throughout the whole algal growth period, and diatoms dominate.

\section{9 th century scenario}

The development of urban population and associated pre-industrial activity in the first half of the 19th century leads to increased phosphorus delivery, enhancing algal growth in the coastal zone. Silica retention in the drainage network reaches $20 \%$ of total inputs, and silica becomes depleted in spring. Nondiatoms take over at the end of spring and in summer and become nitrogen limited. These trends develop until the end of the 19th century, owing to the increasing urban population and industrial activity, which cause still greater point sources of phosphorus, and to the generalization of drainage, which drastically reduces the efficacy of nutrient retention processes.

\section{0th century scenario}

In the beginning of the 20th century, rapid changes in industrial processes lead to lowered contribution of the traditional sectors of industry to nitrogen and phos- 
phorus loading, reversing to some extent the eutrophication of coastal zones observed in the 19th century scenario. From the 1950s, however, intensification of agriculture with the beginning of the large-scale use of nitrogen fertilizers caused an increased nitrogen delivery, particularly in the absence of buffer strips along rivers and streams, enhancing again non-diatom blooms in the coastal zone. Phosphorus again becomes their limiting nutrient. A few decades later, the introduction of polyphosphate-containing washing powders resulted in a 3 -fold increase in the phosphorus delivery, and still higher coastal algal blooms. Silica depletion then occurred at the end of April, and nondiatoms were again limited by nitrogen.

Generalization of biological wastewater treatment, which only became effective in the Phison watershed by the mid 1980s, did not notably affect the point loads of nitrogen and phosphorus. The further increase of the use of nitrogen fertilizers was not enough to bring the coastal system towards phosphorus limitation.

\section{Future management scenarios}

In a scenario where point sources of phosphorus are reduced by both tertiary treatment of urban effluents and $a$ ban on the use of polyphosphate washing powders, $P$ delivery to the coastal zone is reduced by a factor of 7 , resulting in a drastic reversal of the eutrophication process. Phosphorus limitation is now observed throughout the year, while nitrate concentrations remain high.

The corresponding scenario, where tertiary treatment of nitrogen is applied to all point sources of wastewater (denitrification), is much less effective in reducing the nitrogen delivery to the coastal zone, because of the importance of non-point sources of nitrogen. Non-diatom blooms are hardly affected in this scenario with respect to the secondary treatment situation.

Compared with tertiary treatment of urban effluents, the restoration of ponds and riparian zones in the whole drainage network, which strongly reduces the diffuse sources of nitrogen, appears to be a much more efficient measure in reducing nitrogen delivery to the coastal zone and in preventing eutrophication. Combining this with phosphorus treatment of urban wastewater probably provides the best way to reduce coastal eutrophication. While silica and nitrogen are limiting respectively for diatoms and non-diatoms in the scenario with wetlands restoration alone, phosphorus is limiting for both populations throughout the year when accompanied by phosphorus treatment.

\section{DISCUSSION}

The first purpose of the work presented here was to demonstrate the feasibility of the coupling of a model describing a river system and its watershed with a model describing the functioning of a coastal zone affected by riverine nutrient delivery. The succession of events simulated in this exercise, although inspired by previous analyses of the physical conditions and historical evolution of the large river systems of Western Europe (Billen et al. 1991, 1995), is not necessarily of general scope. Other combinations of constraints or other timing in their changes can result in other patterns in their manifestations. Nevertheless, the historical succession of situations simulated in our hypothetical example bears several resemblances with real situations and provides an explanation for some puzzling observations.

The high rolative silica delivery by even pristine rivers and the stimulation of diatoms it induces in its plume with respect to coastal areas not receiving riverine inputs is a well-documented phenomenon. Most open ocean systems, outside regions or periods of upwelling, are dominated by non-diatom communities sustained by regenerated sources of nitrogen and phosphorus, while input of freshwater from unpolluted rivers, in the same way as upwelling of deep oceanic water, primarily stimulates the diatom community (Menzel et al. 1963, Ryther 1969, Pingree 1978, Peterson 1986, Conley \& Malone 1992).

In our scenario for Eden Bight, deforestation and the consequent increase in soil leaching causes a significant stimulation of the diatoms' coastal bloom, however without depletion of silica. Similarly, in Lakes Ontario and Erie (North America), an increase in diatom growth, resulting from deforestation by the early European settlers and subsequent establishment of traditional agriculture in large territories in the watershed, has been demonstrated by the analysis of biogenic silica deposits in sediment cores (Schelske et al. 1983, Stoermer et al. 1985). However, in contrast to the results of our simulations for Eden Bight, these authors clearly showed that the increased inputs of phosphorus to these lakes resulted in the long term exhaustion of silica and a replacement of diatoms by non-siliceous species. The much longer tlushing time of the Great Laurentian Lakes obviously confers upon them a much higher sensitivity compared with Eden Bight (Conley et al. 1993).

The role of both urban wastewater discharge and agricultural soil leaching on coastal eutrophication has often been emphasized (Ryther \& Dunstan 1971, Nixon 1995). Our analysis shows that a significant degree of coastal eutrophication might well have occurred as early as the second half of the 19th century in densely 
populated areas, as a result of both the high early industrial pollution load and the reduced retention capacity of the river systems. This offers an interpretation of the observations mentioned in the 'Introduction' concerning a first wave of eutrophication at the end of the last century.

Our analysis also suggests a considerable variability in the pattern of nutrient limitation of coastal zones under riverine influence, with silica, nitrogen or phosphorus being the limiting nutrient according to the period of the year or the prevailing land use conditions in the catchment. As discussed by several authors (Paasche \& Erga 1988, Thingstad \& Sakshaug 1990, Thingstad \& Rassoulzadegan 1995), prompted by the observation that in some extremely oligotrophic environments algae grow at near maximum growth rates (Goldman et al. 1979), a distinction should be introduced between 'physiological' and 'systemic' nutrient limitation. The former refers to the starvation of individual cells, as demonstrated by physiological indicators or direct measurement of growth rate, while the latter refers to the control of the total biomass of the ecosystem by the restricted amount of 1 element, as can be demonstrated by an increase in biomass during short-term enrichment bioassays (provided they respect the integrity of the whole system). Taking the Eden Bight coastal ecosystem as it is represented by the Zoco Model, both criteria of nutrient limitation can be checked at any time. The model represents the interactions between algal growth and nutrients through Monod-type kinetics, considering no combined nutrient limitation, the lowest of the ratios between ambient nutrient concentration and its corresponding $K_{\mathrm{s}}$ thus defines the 'physiological' limiting nutrient. The model can also simulate a short-term enrichment bioassay by interrupting the calculation at a tested time and increasing the concentration of the tested nutrient. The calculation is then carried on and the calculated phytoplankton or total biomass is compared with the 'control' calculation, allowing for demonstration of 'systemic' limitation. We used both approaches to define the limiting nutrient at the time of maximum diatom and non-diatom development in each land use scenario (Table 3); both criteria were found to provide identical results, indicating that, in the system described, systemic limitation is related to phytoplankton physiological limitation.

Since the early paper by Ryther \& Dunstan (1971), the idea prevails that nitrogen, rather than phosphorus, is the limiting nutrient in most coastal marine systems. In fact the arguments developed by these authors, and the examples they discussed, mainly concern coastal systems receiving heavy loads of wastewater from urban or animal farming areas. On the other hand, evidence of systemic nitrogen limitation does exist for many open ocean or coastal areas (Hecky \& Kilham 1988, Taylor et al. 1995, Graziano et al. 1996). There are, however, clear indications of both physiological and systemic limitation by phosphorus in other coastal areas, as e.g. in the Mediterranean (Berland et al. 1980, Thingstad \& Rassoulzadegan 1995), in the Baltic Sea (Lignell et al. 1992) or in coastal embayments not influenced by river inputs (Smith 1984).

According to the results of our simulations, phosphorus limitation in coastal systems should have been general under pristine and traditional agriculture conditions of the watersheds, while silica limitation of the spring diatom bloom and summer nitrogen limitation of the non-diatom populations might have occurred from the beginning of industrial times. Drastic reduction of point phosphorus discharges, as can be (and indeed often is) achieved through tertiary treatment of urban effluents combined with the ban of polyphosphates from washing powders, can lead again to phosphorus limitation of primary production in the coastal zone.

Acknowledgements. This paper is largely inspired from the work carried out in the scope of several research programmes including the EC Environment 'BINOCULARS' Project, the Belgian SSTC 'Global Change' programme and the French CNRS 'PIREN-Seine' Project.

\section{LITERATURE CITED}

Baldwin LB, Frere MH, Hjelmfelt AT, McGregor GS, Petri LR, Wirth TL, Storch W. Kelman S (1977) Quality aspects of agricultural runoff and drainage. J Irrig Drain Div 103(IR4):475-495

Beaulac MN, Reckhow KH (1982) An examination of landuse nutrient export relationships. Water Res Bull 18: 1013-1024

Bell DT (1978) Dynamics of litter fall, decomposition, and incorporation in the streamside forest ecosystem. Oikos 30:76-82

Benoit M, Saintot D, Gaury F (1995) Mesures en parcelles d'agriculteurs des pertes en nitrates. Variabilité sous divers systèmes de culture et modélisation de la qualité de l'eau d'un bassin d'alimentation. CR Acad Agric Fr 81:175-188

Berland BR, Bonin DJ, Maestrini SY (1980) Azote ou phosphore? Considérations sur le paradoxe nutritionnel de la mer Méditerranée. Oceanol Acta 3:135-142

Billen G (1993) The Phison River system: a conceptual model of $\mathrm{C}, \mathrm{N}$ and $\mathrm{P}$ transformations in the aquatic continuum from land to sea. In: Wollast R, Mackenzie FT, Chou L (eds) Interactions of C, N, P and S biogeochemical cycles and global change. NATO ASI Series 14, Springer-Verlag, Berlin, p 141-161

Billen G, Décamps H, Garnier J, Boët P, Meybeck M, Servais P (1995) River and stream ecosystems: Atlantic river systems of Western Europe (France, Belgium, The Netherlands). In: Cushing CE et al. (eds) River and stream ecosystems, ecosystems of the world, Vol 22, Chap 12. Elsevier, Amsterdam, p 389-418

Billen G, Garnier J, Billen C. Hannon E (1995) Global change in nutrient transfer from land to sea: biogeochemical 
processes in riversystems. Final Report, SSTC Global Exchange Programme (Belgium), December 1995

Billen G, Garnier J, Hanset P (1994) Modelling phytoplankton development in whole drainage networks: the Riverstrahler model applied to the Seine river system. Hydrobiologia 289:119-137

Billen G, Lancelot C, Meybeck M (1991) N, P and Si retention along the aquatic continuum from land to ocean. In: Mantoura RFC, Martin JM, Wollast R (eds) Ocean margin processes in global change. Dahlem Workshop Reports, Wiley, p 19-44

Cadée GC, Hegemann J (1991) Historical phytoplankton data of the Marsdiep. Hydrobiol Bull 24(2): 111-188

Chestérikoff A, Garban B, Billen G, Poulin M (1992) Inorganic nitrogen dynamics in the river Seine downstream from Paris (France). Biogeochemistry 17:147-164

Conley DJ, Malone TC (1992) Annual cycle of dissolved silicate in Chesapeake Bay: implications for the production and fate of phytoplankton biomass. Mar Ecol Prog Ser 81: $121-128$

Conley DJ, Schelske CL, Stoermer EF (1993) Modification of the biogeochemical cycle of silica with eutrophication. Mar Ecol Prog Ser 101:179-192

Cummins KW, Spengler GM, Ward GM, Speaker RM, Ovink RW, Mahan DC, Mattingly RL (1980) Processing of confined and naturally entrained leaf litter in a woodland stream ecosystem. Limnol Oceanogr 25:952-958

Dawson FH (1976) Organic contribution of stream edge forest litter fall to the chalk stream ecosystem. Oikos 27:13-18

Degobbis D (1989) Increased eutrophication of the Northern Adriatic Sea. Mar Pollut Bull 20:452-457

Dillon PJ, Kirchner WB (1975) The effect of geology and land use on the export of phosphorus from watersheds. Water Res 9:135-148

Doering PH, Oviatt CA, Beatty LL, Banzon VF, Rice R, Kelly SP, Sullivan BK, Frithsen JB (1989) Structure and function in a model coastal ecosystem: silicon, the benthos and eutrophication. Mar Ecol Prog Ser 52:287-299

Egge JK, Aksnes DL (1.992) Silicate as regulating nutrient in phytoplankton competition. Mar Ecol Prog Ser 83: 281-289

Fonda Umani S, Ghirardelli E, Specchi M (1989) Gli episodı di 'mare sporco' nell'Adriatico dal 1729 ai giorni nostri. Regione Autonoma del Friuli-Venezia Giula. Pubb Direz Region Ambiente, Trieste

Gächter R, Furrer OJ (1972) Der Beitrag der Landwirtshaft zur Eutrophierung der Gewässer in der Schweiz. Schweiz Z Hydrol 34:41-70

Garnier J, Billen $G_{1}$ Coste M (1995) Seasonal succession of diatoms and chlorophyceae in the drainage network of the River Seine: observations and modelling. Limnol Oceanogr 40:750-765

Goldman JC, McCarthy JJ, Peavey DG (1979) Growth rate influence on the chemical composition of phytoplankton in oceanic waters. Nature 279:210-215

Graziano LM, Geider RJ, Li WKW, Olaizola M (1996) Nitrogen limitation of North Atlantic phytoplankton analysis of physiological condition in nutrient enrichment experiments. Aquat Microb Ecol 11:53-64

Grossel H (1985) Le milieu marin: un milieu vivant et fluctuant: perception par les populations littorales du Nord de la France d'un phénomène planctonique caractérisé. Cah Cent Ethno-Technol Milieu Aquat 2:93-97

Hecky RE, Kilham P (1988) Nutrient limitation of phytoplankton in freshwater and marine environments. A review of recent evidence on the effects of enrichment. Limnol Oceanogr 33:796-822
Herbst GN (1980) Effects of burial on food value and consumption of leaf detritus by aquatic invertebrates in a lowland forest stream. Oikos 35:411-424

Howarth RW, Billen G, Swaney D, Townsend A, Jaworski N. Lajtha $K$, Downing JA, Elmgren $R$, Caraco $N$, Jordan $T$, Berendse F, Freney J, Kudeyarov V, Murdoch $P$, Zhaoliang Z (1996) Regional nitrogen budgets and riverine N, $P$ fluxes for the drainages to the North Atlantic Ocean: natural and human influences. Biogeochemistry 35: $75-139$

Justic D, Legovic T, Rottini-Sandrini L (1987) Trends in oxygen content 1911-1984 and occurrence of benthic mortality in the northern Adriatic Sea. Estuar Coast Shelf Sci 25:435-445

Lancelot C, Billen G (1992) Dynamics of Phaeocystis blooms in nutrient enriched coastal zones. Synthesis report. Contract EV4V-0102-B, CE Environment Programme, DG XII, Brussels

Lancelot C, Billen G, Sournia A, Weisse T, Colijn F, Veldhuis M, Davies A, Wassman P (1987) Phaeocystis blooms and nutrient enrichment in the continental coastal zones of the North Sea. Ambio 16:38-46

Lancelot C, Rousseau V, Billen G, Van Eeckhout D (1997) Coastal eutrophication of the Southern Bight of the North Sea: assessment and modelling. NATO Advanced Research Workshop on 'Sensitivity of North Sea, Baltic Sea and Black Sea to anthropogenic and climatic changes' NATO-ASI Series 2: Environment, Vol 27. Springer-Verlag, Berlin, p 439-453

Lignell R, Kailala S, Kuosa H (1992) Factors controlling phytoand bacterioplankton in late spring on a salinity gradient in the Northern Baltic. Mar Ecol Prog Ser 84:121-131

Marchetti R (1991) Algal blooms and gel production in the Adriatic Sea. In: Barth H, Fegan L (eds) Eutrophicationrelated phenomena in the Adriatic Sea and in other Mediterranean coastal zones. Water Pollut Res Rep Ser no. 16, CEC, DG XII, Brussels, p 21-42

Menzel DW, Hulburt EM, Ryther JH (1963) The effects of enriching Sargasso Sea water on the production and species composition of the phytoplankton. Deep Sea Res 10:209-219

Meybeck M (1982) C, N and P transport by world rivers. Am J Sci 282:401-450

Meybeck M (1986) Composition chimique des ruisseaux non pollués de France. Sci Géol Bull 39:3-77

Nixon SW (1995) Coastal marine eutrophication: a definition, social causes and future concerns. Ophelia 41:199-219

Officer CB, Ryther JH (1980) The possible importance of silicon in manne eutrophication. Mar Ecol Prog Ser 3:83-91

Omernik P (1976) The influence of land use on stream nutrient levels. Ecol Res Ser No. EPA-600/3-76-014, US Environmental Protection Agency, Environment Research Laboratory, Corvallis, OR

Oncklincx F (1991) Les entreprises de blanchiment, de teinture et d'impression sur étoffe à Anderlecht, Forest et Uccle entre 1830 et 1870 . Approche du probleme de la pollution industrielle de la Senne et de ses affluents. Memoire Lic Sp Environm, University of Brussels

Owens NJP, Cook D, Calebrook M, Hunt H, Reid PC (1989) Long term trends in the occurrence of Phaeocystis sp. in the north-east Atlantic. J Mar Biol Assoc UK 69: $813-821$

Paasche E, Erga SR (1988) Phosphorus and nitrogen limitation of phytoplankton in the inner Oslofjord (Norway). Sarsia 93:229-243

Peterson WT (1986) The effect of seasonal variations in stratification on plankton. dynamics in Long Island Sound. In: 
Bowman J, Yentsch M, Peterson WT (eds) Tidal mixing and plankton dynamics. Springer-Verlag, Berlin, p 297-320

Pingree RD (1978) Mixing and stabilization of phytoplankton distributions on the North West European continental shelf. In: Steele JH (ed) Spatial patterns in plankton communities. Plenum Press, New York, p 181-220

Radach G, Berg J, Hagmeier E (1990) Long-term changes of the annual cycles of meteorological, hydrographic, nutrient, and phytoplankton time series at Helgoland and at LV Elbe 1 in the German Bight. Cont Shelf Res 10: 305-328

Richards JF (1990) Land transformation. In: Turner BL (ed) The earth as transformed by human action. Global and regional changes in the biosphere over the past 300 years. Cambridge University Press, Cambridge, p 179-202

Ryther JH (1969) Photosynthesis and fish production in the sea. The production of organic matter and its conversion to higher forms of life vary throughout the world ocean. Science 166:72-76

Ryther JH, Dunstan WM (1971) Nitrogen, phosphorus and eutrophication in the coastal marine environment. Science 171:1008-1013

Sanchez N, Garnier J, Billen G (in press) Denitrification in the sediments of a large reservoir in the upstream Seine basin (Reservoir Marne). Hydrobiologia

Schelske CL, Stoermer EF, Conley DJ, Robbins JA, Glover RM (1983) Early eutrophication in the Lower Great Lakes: new evidence from biogenic silica in sediments. Science 22:320-322

Smith SV (1984) Phosphorus versus nitrogen limitation in the marine environment. Limnol Oceanogr 29:1149-1160

Sommer U (1994) Are marine diatoms favoured by high Si:N ratios? Mar Ecol Prog Ser 115:309-315

Responsible Subject Editor: T. F. Thingstad, Roskilde, Denmark
Sonzogni WC, Jeffs DM, Konrad JC, Robinson JB, Chesters G Coute DR, Ostry RC (1980) Pollution from land runoff Environ Sci Technol 14:148-153

Stoermer EF, Wolin JA, Schelske CL, Conley DJ (1985) An assessment of ecological changes during the recent history of Lake Ontario based on siliceous microfossils preserved in the sediments. J Phycol 21:257-276

Strahler AN (1957) Quantitative analysis of watershed geomorphology. Trans Am Geophys Union 38:913-920

Taylor D, Nixon S, Granger S, Buckley B (1995) Nutrient limitation and the eutrophication of coastal logoons. Mar Ecol Prog Ser 127:235-244

Thingstad TF, Rassolzadegan F (1995) Nutrient limitations, microbial food webs and 'biological C-pumps': suggested interactions in a P-limited Mediterranean. Mar Ecol Prog Ser 117:299-306

Thingstad TF, Sakshaug E (1990) Control of phytoplankton growth in nutrient recycling ecosystems. Theory and terminology. Mar Ecol Prog Ser 63:261-272

Verbanck M, Vanderborght JP, Wollast R (1989) Major ion content of urban wastewater: assessment of per capita loading. J Water Poll Contr Fed 61:1722-1728

Vollenweider RA (1968) Scientific fundamentals of the eutrophication of lakes and flowing waters, with particular reference to nitrogen and phosphorus as factors in eutrophication. Tech Rep DAS/CSI/6827. OECD, Paris

Vought LBM, Dahl J, Pedersen CL, Lacoursière JO (1994) Nutrient retention in riparian ecotones. Ambio 23: $342-347$

Williams M (1990) Forests. In: Turner BL (ed) The earth as transformed by human action. Global and regional changes in the biosphere over the past 300 years. Cambridge University Press, Cambridge, p 179-202

Manuscript received: October 12, 1996

Revised version accepted: January 5, 1997 